\title{
BIODIVERSITY BEYOND NATIONAL JURISDICTION: CURRENT DEBATE AND INDONESIA'S INTEREST
}

\author{
Gulardi Nurbintoro* and Haryo Budi Nugroho**
}

\begin{abstract}
* University of Virginia School of Law, United States; ** Office of the of Special Envoy to the President of the Republic of Indonesia for Maritime Delimitation
\end{abstract}

Article Info

Received : 14 March 2016 | Received in revised form : 10 June 2016 | Accepted : 25 November 2016

Corresponding author's e-mail : r.gulardi_88@yahoo.com,gn4dc@virginia.edu

\begin{abstract}
The drafters of the 1982 UN Convention on the Law of the Sea (UNCLOS) have left behind a lacunae in terms of the regulations concerning Biodiversity in the Areas Beyond National Jurisdiction (BBNJ). As living organisms are found in the deep seabed in areas beyond national jurisdiction, as well as the utilization of marine genetic resources beyond national jurisdiction for commercial purposes, States are currently deliberating on the proper regime in dealing with the management and exploitation of the biodiversity. Some States argue that Part XI UNCLOS applies hence BBNJ is also part of the Common Heritage of Mankind. On the other hand, some States believe that Part VII UNCLOS applies which will allow individual States to exploit the resources in accordance with the principle of the freedom of the high seas. Since 2004, the UN General Assembly has established a Working Group to discuss the issue. Indonesia as a Party to UNCLOS which in general advocates the importance of the rule of law in the oceans has the interest that the discussion in the UN will allow developing countries, including Indonesia, to enjoy the result of the exploration and exploitation of non-mineral resources at the bottom of the ocean.
\end{abstract}

Keywords: Indonesia, UNCLOS, CBD, biodiversity, beyond national jurisdiction

\begin{abstract}
Abstrak
Para perumus Konvensi Hukum Laut PBB 1982 (UNCLOS) telah meninggalkan kekosongan terkait dengan pengaturan mengenai Keanekaragaman Hayati di Luar Yurisdiksi Negara. Seiring dengan ditemukannya mahluk hidup di dasar laut di wilayah di luar yurisdiksi negara, Negara, dan kegunaan sumber daya genetika di luar yurisdiksi negara untuk keperluan komersial. Negara di dunia saat ini berdebat mengenai rezim yang tepat untuk mengatur pengelolaan dan eksploitasi keanekaragaman hayati tersebut. Sebagian berpendapat bahwa rezim Bagian XI UNCLOS yang berlaku sehingga keanekaragaman hayati di dasar lautan yang terdapat area di luar yurisdiksi negara merupakan bagian dari Warisan Bersama Umat Manusia. Di pihak lain terdapat pandangan bahwa rezim yang berlaku adalah Bagian VII UNCLOS sehingga seluruh Negara berhak mengeksploitasi sumber daya dimaksud sesuai dengan prinsip Kebebasan di Laut Lepas. Sejak tahun 2004, Majelis Umum PBB telah membentuk suatu Kelompok Kerja yang bertugas untuk membahas isu dimaksud. Indonesia sebagai Negara Pihak UNCLOS yang secara umum mengadvokasi pentingnya kepastian serta penegakan hukum di laut berkepentingan agar pembahasan di PBB itu dapat membuat negara-negara berkembang, termasuk Indonesia, bisa turut menikmati hasil dari eksplorasi maupun eksploitasi dari sumber daya non-mineral di dasar lautan.
\end{abstract}

Kata Kunci: Indonesia, UNCLOS, cbdCBD, keanekaragaman hayati, luar yurisdiksi negara 


\section{INTRODUCTION}

\section{A. Mare Clausum v. Mare Liberum}

Ever since time immemorial, mankind has always been preoccupied with issues relating to the governance of the ocean. The debate on whether oceans could be claimed by a sovereign nation could be traced back to 1494 when the Treaty of Tordesillas was signed. The Treaty encompassed an agreement between the Kingdom of Spain and the Kingdom of Portugal to divide the sea containing discovered and to be discovered islands between the two nations. ${ }^{1}$ The Treaty embodied the principle of Mare Clausum, argued that by the law of nature and law of nations the sea is subject to private dominion and property. ${ }^{2}$

The Mare Clausum principle was contested predominantly through the work of Hugo Grotius, with a pamphlet titled Mare Liberum in which he sought to justify the overseas naval expansion of the Netherlands. Grotius argued that the sea, by its nature, was incapable of occupation, hence it could not be owned. ${ }^{3}$ He reasoned that securing a permanent occupation was impossible, that ocean resources were inexhaustible, that maritime boundary delimitation was an extremely difficult task, and that the seas were too large that it would be unlikely for a conflict to emerge. It was obviously an argument that could not stand today as modern technology has made the abovementioned impossibilities now possible. ${ }^{4}$ Grotius asserted that the sea is a "natural community" as the sea does not belong to anyone. The sea was res nullius. Therefore, according to Grotius, what does not belong to anyone is open to everyone. ${ }^{5}$ With that, Grotius established the basic concept of freedom of navigation in international law of the sea. ${ }^{6}$

Fast forward to the $20^{\text {th }}$ Century, the 1982 United Nations Convention on the Law of the Sea (UNCLOS)_-also referred to as the Constitution for the Oceans, lays out comprehensive rules of rights and obligation of all States in the ocean - a compromise between Mare Clausum and Mare Liberum. It established the maximum breadth of territorial sea which coastal states have full sovereignty, a contiguous zone for law enforcement purposes, archipelagic waters as part of archipelagic states, an Exclusive Economic Zone (EEZ) and Continental Shelf regime for resources and other limited jurisdiction of the coastal states. It also established rights of other user states, which includes the innocent passage, transit passage and archipelagic sea-lane passages, and the freedom of the high seas. Another milestone created by 1982 UNCLOS is the regulation of the establishment of the Common Heritage of Mankind regime of the

\footnotetext{
${ }^{1}$ Henry Harrisse, The Diplomatic History of America (London: B. F. Stevens Publisher, 1897), p. 72.

${ }^{2}$ Eric Fletcher, "John Selden and His Contribution to International Law," Transactions Grotious Society 19, no. 1 (1933): 9.

${ }^{3}$ Martine Julia van Ittersum, "Mare Liberum versus the propriety of the seas? The debate between Hugo Grotius (1583-1645) and William Welwood (1552-1624) and its impact on Anglo-Scotto-Dutch fishery disputes in the second decade of the seventeenth century," Edinburgh Law Review 10, no. 2 (April 2006): 251.

${ }^{4}$ Ted L. McDorman, et. al., International Ocean Law, Materials and Commentaries (Durham: Carolina Academic Press, 2005), p. 16.

${ }^{5}$ Ibid.

${ }^{6}$ A renowned British lawyer, John Selden, published in 1635 his writing titled Mare Clausum as a response towards Grotious' Mare Liberum. The aim was to defend the rights of states to control the oceans, and to emphasize that "the lordship of the circumfluent and surrounding ocean belongs to the Crown of Great Britain, as an inseparable and perpetual appendage." Fletcher, “John Selden”, pp. Su9-10.
} 
Area, the ocean floor beyond national jurisdiction.

\section{B. Indonesia and the Law of the Sea}

The Mare Clausum v. Mare Liberum debate is very much related to Indonesia's position in the formation of the ocean legal order. During the negotiation of UNCLOS, Indonesia was one of the key players-particularly with its archipelagic state principle. In 1957, Indonesia proclaimed the Djuanda Declaration which was a manifestation of how Indonesia perceived itself. Indonesia believed that its sea and its land was a whole unit that could not be separated from each other, hence Indonesians reference to their homeland as Tanah Air, meaning Land and Water.

Prior to the Declaration, Indonesia inherited from the Netherlands a belt of territorial waters of 3 nautical miles for each island of the Indonesian archipelago in accordance with the Territorial Waters Ordinance 1939. The 1939 Ordinance caused the existence of high seas or international waters in between Indonesian islands. This Declaration was subsequently formalized through the Government Regulation in lieu of Law No. 4 of the Year 1960 on Indonesian Waters. The new law established Indonesia's territorial waters at 12 nautical miles from the baselines drawn from the outermost points of the outermost islands of Indonesia. ${ }^{7}$

Indonesia brought the matter to the first and second law of the sea conferences. At first, this principle was not accepted by the international community. It was not included in the 1958 Geneva Conventions on the Law of the Sea. Nevertheless, through series of negotiations, the archipelagic state principle gained acceptance in the 1982 UNCLOS. Various criteria were established in Part IV of UNCLOS, and as a compromise the right of archipelagic sea-lane passage was established to accommodate the navigation interest of other states. The Djuanda Declaration with its archipelagic state concept was considered a breakthrough in the area of law, politics, economy, cultural, territorial integrity, and national unity. ${ }^{8}$ Hence, the international recognition of the concept following the adoption of UNCLOS was considered as one of the most important diplomatic achievements in Indonesian history.

\section{Current Development: Legal Lacunae for the BBNJ}

One of the major achievements of UNCLOS was the establishment of the regime of the Area. In fact, it was the questions on utilization of resources beyond national jurisdiction that became the driving factor to convene the Third United Nations Conference on the Law of the Sea which led to the adoption of UNCLOS. In 1967 the Government of Malta proposed to the United Nations Secretary General a draft Declaration and Treaty Concerning the Reservation Exclusively for Peaceful Purpose of the Sea-bed and of the Ocean Floor, Underlying the Sea beyond the limits of Present National Jurisdiction, and the Use of their Resources in the Interest of Mankind. The request went along with a statement that the time has come to declare the ocean floor

\footnotetext{
${ }^{7}$ Indonesia, Peraturan Pemerintah Pengganti Undang-Undang tentang Perairan Indonesia (Government Regulation in lieu of Law on Indonesian Waters), Perpu No. 4 Tahun 1960, LN No. 22 tahun 1960, TLN No. 1942 (Government Regulation in lieu of Law No. 4 of 1960, SG No. 22 of 1960), art. 1 para 2.

${ }^{8}$ Nugroho Wisnumurti, "Rezim Hukum Negara Kepulauan [Legal Regime of an Archipelagic State]," Kompas (Jakarta), 18 March 2014.
} 
and the seabed as a common heritage of mankind. ${ }^{9}$

The suggestion of Malta was followed by subsequent recommendations for declaring the high seas and the seabed beyond the limits of national jurisdiction as common heritage of mankind. ${ }^{10}$ Ambassador Arvid Pardo of Malta also submitted a Memorandum to the General Assembly that an area designated as a common heritage of mankind should not be subjected to national appropriation, and should also be reserved for peaceful purposes. ${ }^{11}$ As a response towards the call, the General Assembly adopted Resolution 2749 (XXV) in 1970 declaring solemnly that the seabed and ocean floor, and the subsoil thereof, beyond the limits of national jurisdiction, are the common heritage of mankind..$^{12}$ It further declared that appropriation of the area should not be allowed and no claim of sovereignty or sovereign rights should take place. ${ }^{13}$ The regime of the seabed beyond national jurisdiction, or the Area, are then incorporated as Part XI of UNCLOS. Part XI however was later "amended" by the provisions of the 1994 Agreement relating to the Implementation of Part XI of UNCLOS (Implementing Agreement).

During the period when UNCLOS was negotiated, the world had little knowledge on the existence of living resources in the areas beyond national jurisdiction, particularly in the Area. It was assumed initially that the lack of sunlight in the ocean floor made photosynthesis impossible. ${ }^{14}$ This lack of knowledge led the drafters of UNCLOS to focus on mineral resources and left out the living resources. Experts did not think about genetic resources from the seabed nor the water columns when they drafted UNCLOS. They also did not pay attention to the immense values of genetic resources even after the discovery of the hydrothermal vent in $1977 .{ }^{15}$ Living resources of the water column of high seas was handled to answer fisheries concern only, particularly for highly migratory species and straddling stocks. With the development of modern technology, the potential benefit from these resources became more apparent, including for pharmaceutical purposes, and yet no comprehensive regulation is available.

Taking into account the discoveries made with respect to living resources in areas beyond national jurisdiction and their current inability to extract the benefit from the living resources at the seabed and ocean floor, developing countries push to recognize these resources as common heritage of mankind, hence falling within the scope of Part XI. On the other hand, developed countries as well as marine scientists

\footnotetext{
${ }^{9}$ Bradley Larschan and Bonnie C. Brennan, "The Common Heritage of Mankind Principle in International Law," Columbia Journal of Transnational Law 21 (1982-1983): 318.

${ }^{10}$ It deserves, however, to be noted that Malta was not the first to introduce the concept of common heritage of mankind. In 1830, Andres Bello, an international jurist from South America, expressed his belief that things should be considered as "indivisible common patrimony" if it could not be held by any nation without affecting others. See Helmut Tuerk, Reflections on the Contemporary Law of the Sea (Leiden, the Netherlands: Martinus Nijhoff, 2012), p. 31. Further expression of common heritage of mankind was stated by Prince Wan Watlagakon of Thailand during the 1958 Law of the Sea Conference. See Larschan and Brennan, "The Common Heritage", at footnote 45.

11 Ibid., p. 33.

12 United Nations, General Assembly, Declaration of Principles Governing the Sea-Bed and the Ocean Floor, and the Subsoil Thereof, beyond the Limits of National Jurisdiction: Resolution 2749 (XXV), A/ RES/25/2749, (17 December 1970).

13 Ibid.

14 Fernanda Millicay, "A Legal Regime for the Biodiversity of the Area" in Law, Science, and Ocean Management, Myron H. Nordquist et. al. ed. (Leiden: Martinus Nijhoff, 2007), p. 745.

15 Friederike Lehmann, "The Legal Status of Genetic Resources of the Deep Seabed," New Zealand Journal of International Law 11, no. 33 (2007): 39.
} 
and biotechnology-interested entities argue that these resources fall under the scope of Part VII UNCLOS. ${ }^{16}$ Hence, the international community was divided on the proper regime to regulate biological resources within the context of UNCLOS. Consequently, the issue of living resources became a legal lacuna yet to be resolved.

\section{Organization of this Paper}

Following this introduction, the paper will proceed to explain further the BBNJ issues that are left out by the current international legal system. Chapter II will explain the relation between different international law instruments related to the issues of BBNJ. Besides the UNCLOS, this paper will also discuss the Convention on Biological Diversity (CBD) as well as the framework of the World Intellectual Property Organization (WIPO) with regard to genetic resources.

This paper will then elaborate on the current discussion under the UN framework, particularly the Ad-hoc Open-ended Informal Working Group to study issues relating to the conservation and sustainable use of marine biological diversity beyond areas of national jurisdiction (BBNJ Working Group). It will briefly explain the underlying debates as well as position of states with regard to the BBNJ issue.

In Chapter IV, the paper will highlight Indonesia's direct interest in the development of the BBNJ regulation. It will explain why Indonesia has both general interest as part of the international community as well as distinct interest with regard to the regulation of the BBNJ. Finally, this paper will present its conclusion and recommendation.

\section{THE CURRENT LEGAL REGIME}

\section{A. Scope of Biodiversity Beyond National Jurisdiction (BBNJ)}

In order to understand the term Biodiversity Beyond National Jurisdiction (BBNJ) one may have to refer to two international conventions. First is the Convention on Biological Diversity (CBD) and the second is UNCLOS.

The CBD defined biological diversity as follow:

"The variability among living organisms from all sources including, inter alia, terrestrial, marine and other aquatic ecosystems and the ecological complexes of which they are part: this includes diversity within species, between species and of ecosystems."17

Although the CBD also uses the term "areas beyond the limits of national jurisdiction," 18 the CBD did not further elaborate it. Reference then have to be made by interpreting relevant provisions of UNCLOS which divided the ocean into maritime zones where the jurisdiction of states are regulated.

The UNCLOS granted the right to Coastal States to claim a belt of Territorial Sea up to 12 nautical miles from its baseline. ${ }^{19}$ Coastal States were further given the right to claim a Contiguous Zone up to 24 nautical miles measured from its baselines, ${ }^{20}$ and an

\footnotetext{
${ }^{16}$ Larschan and Brennan, "The Common Heritage," p. 47

17 Convention on Biological Diversity, Rio de Janeiro, 5 June 1992, United Nations Treaty Series, Vol. 2237, No. 31363, Art. 2. (hereinafter “CBD”)

${ }_{18}$ Ibid., art. 3.

19 Convention on the Law of the Sea, Montego Bay, 10 December 1982, United Nations Treaty Series Vo. 1833, Art. 3. (hereinafter "UNCLOS")

${ }^{20}$ Ibid., art. 33 para. 2.
} 
Exclusive Economic Zone (EEZ) up to 200 nautical miles. ${ }^{21}$ Additionally, coastal states enjoy the inherent right of a Continental Shelf that may extend up to 200 nautical miles or more provided the coastal State can provide a scientific evidence that the seabed exceeding the 200 nautical miles limit is a natural prolongation. ${ }^{22}$ It should be noted that the sovereign rights of the Coastal State in the EEZ and Continental Shelf are limited mainly for its natural resources, while the right to freedom of navigation of other States applies. It could thus be concluded that beyond national jurisdiction means the area of which states has no sovereignty or sovereign rights over the waters and subsoil thereof.

Areas beyond national jurisdiction are therefore the High Seas and the Area. Freedom of the seas are recognized ${ }^{23}$ and no sovereignty claim could be accorded in the high seas. ${ }^{24}$ The Area is defined by UNCLOS as "the seabed and ocean floor and subsoil thereof, beyond the limits of national jurisdiction". 25

From the definitions presented above, it can be drawn into conclusion that the generic scope of BBNJ concerns the governance - which includes its utilization and conservation - of living organisms that exist in areas that cannot be put under any country's sovereignty or sovereign rights.

\section{B. UNCLOS Provisions}

Part VII of UNCLOS governs issues relating to High Seas and the freedom of the seas. The provisions of High Seas in UNCLOS are similar to the High Seas Convention 1958. UNCLOS, however, added two high seas freedom compared to the High Seas Convention 1958. Those are freedom to construct artificial islands and other installations as well as the freedom to conduct scientific research. ${ }^{26}$

The basic premise of the freedom of the high seas as reflected in Article 87 Para. 1 UNCLOS indicates that States have the widest freedom to engage in activities in this part of the ocean as long as they do not claim it to be under their sovereignty. ${ }^{27}$ Yet, the activities in the high seas have to respect the interests of other States. Furthermore there remains an obligation for States to preserve and protect marine environment through the conservation of the living resources at the high seas. ${ }^{28}$

The most relevant freedom of the high seas with regard to the issue of BBNJ is the freedom of fishing, freedom of marine scientific research, and the conservation and management of the living resources of the high seas. All states have the rights to fishing on the high seas while at the same time they are bound to their treaties obligations and provisions concerning the interests of Coastal States with respect to straddling stocks, highly migratory species, marine mammals, anadromous stocks, and catadromous species. ${ }^{29}$ While exercising their rights to fish in the High Seas, States

\footnotetext{
21 Ibid., art. 57.

${ }^{22}$ Ibid., art. 76. A State must make a submission to the Commission on the Limits of Continental Shelf when claiming a continental shelf beyond 200 nautical miles. Article 76 provides a maximum distance limit for claims beyond 200 nautical miles.

${ }^{23}$ Ibid., art. 87 para. 1.

24 Ibid., art. 89.

${ }^{25}$ Ibid., art. 1 para. 1.

${ }^{26}$ Ibid., art. 87 para. 1.

27 Ibid., art. 89.

28 Ibid., art. 118.

${ }^{29}$ Ibid., art. 116.
} 
are obliged to use the best scientific evidence to determine the allowable catch. At the same time the measures taken by a State with respect to conservation measures in the High Seas shall not discriminate against fishermen of other States. ${ }^{30}$ The provisions concerning marine scientific research are elaborated in Part XIII of UNCLOS. All states have the right to conduct marine scientific research. ${ }^{31}$ However no definition of marine scientific research could be found in UNCLOS. The right to conduct marine scientific research at High Seas was repeated in a rather vague term in Article 257 of UNCLOS. ${ }^{32}$ The Convention sets out guidelines that marine scientific research should be conducted exclusively for peaceful purpose using appropriate scientific methods which shall not interfere with other legitimate uses of the sea and in compliance with all adopted regulations relating to the protection and preservation of marine environment. ${ }^{33}$

The protection of marine environment is lined out in Part XII. The provisions in Part XII did not specifically mention about High Seas, but govern in general all maritime zones. The obligation to prevent, reduce, and control pollution of the marine environment could be inferred from Article 194 Para. 2. The Article stipulated that activities under their jurisdiction or control should not cause damage to other States and their environment. The term 'under their jurisdiction' could also be interpreted as vessels flying a flag of a particular State in the High Seas of which exclusive jurisdiction is considered over the vessel. ${ }^{34}$ States are responsible to fulfill their international obligations concerning the protection and preservation of the marine environment under international law. ${ }^{35}$

Part XI of UNCLOS governs issues relating to the seabed beyond national jurisdiction, the Area. As a general rule, Article 136 of UNCLOS declared the Area and its resources as common heritage of mankind. Therefore, the rights in the resources of the Area are attributed to mankind. However it limits the definition of "resources" only to solid, liquid or gaseous mineral resources in situ in the Area at or beneath the sea-bed.

Part XI of UNCLOS also established the International Seabed Authority (ISA) to organize and control activities in the Area, especially in administering the resources of the Area. ${ }^{36}$ The ISA was tasked in particular to deal with the profit sharing of the revenues arising out of the activities carried out in the Area. ${ }^{37}$ The benefit sharing of the Area mechanism was framed under Part XI to take into consideration "the interests of developing States and peoples who have not attained full independence or other selfgoverning status". ${ }^{38}$ ISA was further required by UNCLOS to "acquire technology and scientific knowledge relating to activities in the Area", and "to promote and encourage the transfer to developing States of such technology and scientific knowledge". ${ }^{9}$ Member States of the ISA (all Parties to UNCLOS) are required to facilitate the access

${ }^{30}$ Ibid., art. 119.

31 Ibid., art. 238

32 Ibid., art. 257. The article did not explicitly mention High Seas. It uses the wording “...the right, in conformity with this Convention, to conduct marine scientific research in the water column beyond the limits of the exclusive economic zone."

${ }^{33}$ Ibid., art. 240.

${ }^{34}$ Ibid., art. 92 para. 1.

35 Ibid., art. 235 para. 1

36 Ibid., art. 157 para.1.

37 Ibid., art. 140 para. 2.

${ }^{38}$ Ibid., art. 160 para. 2 (f)(i).

${ }^{39}$ Ibid., art. 144 para. 1. 
of the Enterprise and developing States to the relevant technology, and providing opportunities for the personnel of the Enterprise and developing states for training in marine science and technology. ${ }^{40}$ The provisions of Part XI concerning the benefit sharing mechanism and the transfer of technology became the source of debate, which led to the rejection of developed States, notably the United States, to become a Party to UNCLOS. They threatened not to become a Party unless substantial changes are made. ${ }^{41}$ This eventually led to the negotiation of the Implementing Agreement of Part XI which fundamentally replaced the applications of deep seabed mining provisions of Part XI UNCLOS. ${ }^{42}$

Other provisions relating to the protection of marine environment and marine scientific research as part of the activities carried out in the Area are also regulated under UNCLOS. The Authority was asked to adopt rules that regulate the prevention, reduction, and control of pollution to the marine environment. ${ }^{43}$ The regulations shall also address the protection and conservation of the natural resources of the Area. ${ }^{44}$

\section{The Debate concerning the Lacunae from UNCLOS Provisions}

UNCLOS did not include BBNJ as part of the resources of the Area. Although it did say that the Area itself is a common heritage, there is no further regulation with regard to the living resources of the Area. In the same vein, Article 135 UNCLOS stipulates that the legal status of the waters above the Area shall not be affected by Part XI, hence its remains as High Seas. Consequently, on the underlying debate over the BBNJ concerns, which regime apply? Is it the common heritage of mankind or the freedom of the high seas?

Several industrialized States believe that freedom of the seas applies to access and use of biological resources, including marine genetic resources. They view a potential regulation of bioprospecting as a hindrance to scientific research which impedes the freedom of navigation. ${ }^{45}$ They further argue that biological resources on the seabed and the ocean floor in the Area also fall under the regime of the freedom of the high seas. ${ }^{46}$ This is because fishing and marine scientific research are not defined under UNCLOS, hence allowing a broad interpretation of the terms in a good-faith to include the collection of deep seabed organisms or microbes. ${ }^{47}$

The shortcomings of the proponents of the freedom of the high seas regime is that it neglects the fact that the utilization of the living resources for fisheries purpose differs from marine genetic resources. As there is no definition of marine scientific research, it is particularly difficult to determine when the result of such research

\footnotetext{
${ }^{40}$ Ibid., art. 144 para. 2.

41 A list of nine problems relating to Part XI was drawn by the developed States during the informal consultations process. These were costs to State Parties, the Enterprise, decision-making, the review conference, transfer of technology, production limitation, the compensation fund, financial terms of contracts and the environment. See James Harrison, Making the Law of the Sea, A Study in the Development of International Law (Cambridge: Cambridge University Press, 2011), p. 89.

42 Ibid., p. 91.

43 UNCLOS, art. 145 (a).

44 Ibid., art. 145 (b).

45 L.A. de La Fayette, "A New Regime for the Conservation and Sustainable Use of Marine Biodiversity and Genetic Resources Beyond the Limits of National Jurisdiction," The International Journal of Marine and Coastal Law 24, (2009): 261.

${ }^{46}$ Ibid.

47 Lehmann, "The Legal Status”, p. 44.
} 
starts to become commercially viable which distinguishes a research as part of the freedom of the high seas and a research which potentially leads to the utilization of genetic resources.

The argument of the developed states was also criticized by La Fayette, who emphasized that the freedom of the seas require States to participate in the activities on the oceans on the basis of equality. This means that they are not free to do whatever they please and should refrain themselves from thinking that the first-come firstserve rule applies. ${ }^{48}$

The view of the developing countries was that living and genetic resources of the seabed in the Area accord the status of common heritage of mankind. ${ }^{49}$ Several developing states also view that the International Seabed Authority will also have to administer living and genetic resources in the Area, something that was not prescribed in UNCLOS. This view, however, would require an amendment of Part XI.

The arguments of the developing countries face opposition by rule of interpretation of the Vienna Convention on the Law of Treaties (VCLT). The Convention requires a treaty to be interpreted in good faith in accordance with the ordinary meaning of the treaty. ${ }^{50}$ In light of the VCLT, the ordinary meaning of Part XI does not imply living resources as part of common heritage of mankind because Article 133 UNCLOS limits "resources" only to mineral resources. However, Article 136 UNCLOS stipulates that "the Area and its resources are the common heritage of mankind", separating the term "Area" and "the Area's resources". This would support the view that BBNJ is considered as part of the Area itself, and thus a common heritage of mankind.

It is also argued that UNCLOS should also be interpreted within their context in the light of its object and purpose. ${ }^{51}$ It is argued that the object and purpose of the Convention could be interpreted from the Preamble of UNCLOS. The Preamble desires the equitable and efficient utilization of sea resources and will "contribute to the realization of a just and equitable international economic order which takes into account the interests and needs of mankind as a whole and, in particular, the special interests and needs of developing countries". ${ }^{52}$ Furthermore, the Preamble cites the 1970 Declaration of Principles resolution by the General Assembly which extends the concept of common heritage of mankind into a broader meaning than mentioned under Article 133 and Article 136 UNCLOS. $^{53}$

Neither interpretation of UNCLOS is satisfying in answering which regime applies for the BBNJ.

\section{Convention on Biological Diversity}

The Convention on Biological Diversity (CBD) was concluded under the auspices of the United Nations Environment Programme (UNEP). The preliminary negotiations took place in November 1988 in the Ad Hoc Working Group of Experts on Biological Diversity. The Working Group was deliberating on the need for an international

\footnotetext{
${ }^{48}$ de La Fayette, “A New Regime," p. 261.

49 Lehmann, "The Legal Status", p. 44.

50 Convention on the Law of Treaties, Vienna, 23 May 1969, United Nations Treaty Series, Vol. 1155, No. No. 18232 , art. 31 para. 1 . (hereinafter "VCLT")

51 Ibid.

${ }^{52}$ Lehmann, "The Legal Status", p. 45.

53 Ibid.
} 
convention on biological diversity. ${ }^{54}$ The Working Group was known by February 1991 as the Intergovernmental Negotiating Committee. The Committee gathered in 1992 in Nairobi, Kenya and adopted the agreed text of the CBD which was then opened for signature during the United Nations Conference on Environment and Development in Rio de Janeiro, Brazil. The CBD entered into force on 29 December 1993. ${ }^{55}$ As of now there are 196 States who have become Parties to CBD. ${ }^{56}$

The CBD noted in its preamble that conservation of biological diversity is a common concern of humankind and that human activities have significantly reduced biological diversity. Therefore, the CBD aimed to conserve biological diversity, and regulate the sustainable use of its components and equitable sharing of the benefits deriving from the utilization of genetic resources. This might include the transfer of technologies as well as appropriate funding. ${ }^{57}$

The principle of the CBD recognized the responsibility of States to ensure that activities within their control or jurisdiction do not cause environmental damage to other States or to the areas beyond national jurisdiction. ${ }^{58}$ The CBD applies to areas within the limits of national jurisdiction in the case of components of biological diversity, while in the case of processes and activities the CBD applies in areas within as well as beyond national jurisdiction..$^{59}$ This provision indicates that the conservation of the components of biological diversity beyond national jurisdiction does not fall within the application of the CBD.

However, the provisions concerning genetic resources are limited within the scope of the sovereign rights of States over their natural resources within their own jurisdiction. Article 15 of the CBD limits its scope by stating "Recognizing the sovereign rights of States over their natural resources". ${ }^{60}$ Therefore, it does not apply to areas beyond national jurisdiction because of the absence of sovereign rights over the resources.

To further implement Article 15 of the CBD, the $10^{\text {th }}$ Meeting of the Conference of the Parties to the CBD adopted the Nagoya Protocol. ${ }^{61}$ Its objective was to ensure fair and equitable sharing of the benefits arising from the utilization of genetic resources. ${ }^{62}$ The Protocol provided a legal framework for the effective implementation of one of the three objectives outlined by the CBD. The Nagoya Protocol was deemed important as it established more predictable conditions for access to genetic resources and ensuring the benefit sharing mechanism takes place when genetic resources leave the state which provides the genetic resources. ${ }^{63}$ As of now there are 69 States which have

\footnotetext{
${ }^{54}$ Convention on Biological Diversity Website, "History of the Convention," available at https://www. cbd.int/history/, accessed on 22 February 2016.

55 Ibid.

56 Convention on Biological Diversity Official Website, "List of Parties", available at https://www.cbd. int/information/parties.shtml, accessed on 1 March 2016. Indonesia became Party to CBD on 21 November 1994 upon its ratification on 23 August 1994.

${ }^{57}$ CBD, art. 1.

${ }^{58}$ Ibid., art. 3.

${ }^{59}$ Ibid., art. 4.

${ }^{60}$ Ibid., art. 15

61 Conference of the Parties (COP) 10 Convention on Biological Diversity, Decision X/1, Access to Genetic Resources and the Fair and Equitable Sharing of Benefits Arising from their Utilization, October 2010.

62 Nagoya Protocol, Nagoya, 29 October 2010, art. 1.

${ }^{63}$ Convention on Biological Diversity Official Website, "About the Nagoya Protocol", available at https:// www.cbd.int/abs/about/default.shtml/, accessed on 1 March 2016.
} 


\section{become Parties to the Protocol. ${ }^{64}$}

The Nagoya Protocol is a supplementary document to the Convention on Biological Diversity, hence the application of the genetic resources is the same as in the Convention. The scope is limited to the resources located within the national jurisdiction of the Party. Therefore, although the Nagoya Protocol provides regulation on access to genetic resources, it does not provide answer for BBNJ.

\section{E. Intellectual Property Rights of Marine Genetic Resources}

Certain marine genetic resources newly found in the deep seabed have shown potential in the application towards pharmaceuticals, bioremediation, and cosmetics. ${ }^{65}$ The developments and potentials of marine genetic resources in deep seabed raise the questions concerning intellectual property rights. The Agreement on Trade-Related Aspects of Intellectual Property Rights (TRIPS) requires patents for inventions to be new, involving an inventive step and capable of industrial application. ${ }^{66}$ The owner of the patent right may prevent third parties from the acts of making, using, offering for sale, selling, or importing the patented products without the owner's consent. ${ }^{67}$ If the patented object is a process, the owner may prevent third parties from using the process. ${ }^{68}$ A State may, however, impose limited exceptions to the exclusive rights conferred upon a patent owner. ${ }^{69}$

Under the patent law, a distinction is made between the term 'discovery' and 'invention'. A discovery means the finding of an object or organism that have already existed before. An invention requires another process involving human intervention to develop the organism..$^{70}$ The discourse developed into the question whether inventions deriving from naturally genetic material should be considered as new and inventive. There is a different opinion between developed countries and developing countries on this matter. Certain developed countries allow biological organisms in their natural form to be patented, while developing countries deem this as nonpatentable. The difference arises from the provision which subjects "invention" to internal law of Member States. ${ }^{71}$ Furthermore, the definite commercial application of marine genetic resources were unknown which raises another question on the patentability since one of the requirement for patent to be granted is the specific use of the patented object. ${ }^{72}$

The World Intellectual Property Organization (WIPO) established the Intergovernmental Committee on Intellectual Property and Genetic Resources, Traditional Knowledge Folklore (IGC) in 2000. Its purpose was to become a forum for

64 Ibid., "Parties to the Nagoya Protocol", available at https://www.cbd.int/abs/nagoya-protocol/ signatories/default.shtml, accessed on 1 March 2016. Indonesia became Party to the Protocol on 12 October 2014 after ratifying it on 24 September 2013

${ }_{65}$ Kirsten E. Zewers, “Debated Heroes from the Deep Sea - Marine Genetic Resources," http://www. wipo.int/wipo_magazine/en/2008/02/article_0008.html, accessed on 23 February 2016.

${ }^{66}$ Agreement establishing the World Trade Organization Annex $1 C$ on Trade-Related Aspects of Intellectual Property Rights, Marrakesh, 15 April 1994, United Nations Treaty Series, Vol. 1867, No. 31874, art. 27 para. 1. (hereinafter "TRIPs")

${ }^{67}$ Ibid., art. 28 para. 1(a).

${ }^{68}$ Ibid., art. 28 para. 1 (b).

69 Ibid., art. 30.

70 Millicay, “A Legal Regime”, p. 794.

${ }^{71}$ Ibid., p. 795.

72 Zewers, "Debated Heroes" 
discussing intellectual property issues that arises in the context of access to genetic resources and benefit-sharing as well as the protection of traditional knowledge and traditional cultural expressions. ${ }^{73}$ The IGC has endeavored to draft a legal instruments that deals with intellectual property and genetic resources. However, up to its $29^{\text {th }}$ session held in Geneva on 15-19 February 2016, the draft has not yet been adopted. According to the provisions of the latest draft, disclosure is required for a claimed invention deriving from genetic resources, ${ }^{74}$ however, an exception to this clause will apply in the case of genetic resources from areas beyond national jurisdiction. ${ }^{75}$

It can be concluded that the question of genetic resources within the context of intellectual property rights has yet to be resolved. Adding complexity to the problem, marine genetic resources beyond national jurisdiction possess two issues. First, the issue with its intellectual property, and second, concerning the ownership due to its origin which came from areas beyond national jurisdiction. It will become a challenge when formulating the BBNJ regime since it has to take into account the intellectual property consideration to prevent fragmentation or even inconsistency in the international regulation as a whole.

\section{TOWARDS AN INTERNATIONAL TREATY ON BBNJ}

\section{A. The Early Development of the BBNJ Discussion}

It is apparent that the regime applicable for BBNJ is yet to be regulated. The discussion leading to this questions has begun many years ago. Among the important milestone of this discussion began with the Second Conference of the Parties (COP) of the CBD held in Jakarta, Indonesia in November 1995. It adopted Decision II/10, which requested the Executive Secretary to undertake a study of the relationship between the CBD and UNCLOS regarding the conservation and sustainable use of genetic resources in the deep seabed. ${ }^{76}$ The 2003 Study came out with three options for the management of activities relating to genetic resources in the areas beyond national jurisdiction. First was to maintain status quo, second was to apply the regime of Part XI UNCLOS, and third option was to apply the regime of conservation and sustainable use of genetic resources under CBD. ${ }^{77}$ The study suggested that the three types of regime have the same objective. This objective was to fill the legal lacunae that exists both in UNCLOS and in CBD with respect to the conservation and sustainable use of genetic resources in areas beyond national jurisdiction. ${ }^{78}$

In the same vein, the need to address the legal lacunae was also discussed by the

73 World Intellectual Property Organization, General Assembly, Report of the Twenty-Sixth (12th Extraordinary) Session in Geneva, 25 September - 3 October 2000, WO/GA/26/10, (3 October 2000), Para. 71.

74 ICIPGRTKF, Consolidated Document Relating to Intellectual Property and Genetic Resources for the 29th Session 15 - 19 February 2016, WIPO/GRTKF/IC/29/4, (30 November 2015), Annex, p. 7, art. 3.

75 Ibid., art. 4.

76 Report of the Second Meeting of the Conference of the Parties to the Convention on Biological Diversity, Decision II/10: Conservation and Sustainable Use of Marine and Coastal Biological Diversity, (30 November1995). Para. 12.

${ }^{77}$ United Nations Environmental Programme, "Study of the relationship between the CBD and UNCLOS with regard to the conservation and sustainable use of genetic resources on the deep seabed" in Marine and Coastal Biodiversity: Review, Further Elaboration and Refinement of the Programme of Work, UNEP/CBD/ SBSTTA/8/INF/3/Rev.1, (22 February 2003), Para. 128.

78 Ibid.., Para. 129. 
Secretary-General of the United Nations in its reports ${ }^{79}$, the United Nations General Assembly in its Resolutions on Oceans and the Law of the Sea ${ }^{80}$, as well as the United Nations Open-ended Informal Consultative Process on Oceans and the Law of the $\mathrm{Sea}^{81}$. All of these processes eventually led to the establishment of the Ad Hoc Openended Informal Working Group (Working Group) established by the United Nations General Assembly.

The Working Group was given the following tasks as stipulated under Paragraph 73 of the UN General Assembly Resolution 59/24:

" $a$. To survey the past and present activities of the United Nations and other relevant international organizations with regards to the conservation and sustainable use of marine biological diversity beyond areas of national jurisdiction;

b. To examine the scientific, technical, economic, legal, environmental, socioeconomic and other aspects of these issues;

c. To identify key issues and questions where more detailed background studies would facilitate consideration by States of these issues;

d. To indicate, where appropriate, possible options and approaches to promote international cooperation and coordination for the conservation and sustainable use of marine biological diversity beyond areas of national jurisdiction." ${ }^{\prime 2}$

The first meeting of the Working Group was held in New York in February 2006. The second meeting was further held from 28 April to 2 May 2008 in New York whereby the Working Group discussed the genetic resources beyond national jurisdiction as well as how to address a governance or regulatory gap. ${ }^{83}$ In the third meeting, the Working Group asked the General Assembly to "call upon States...to make progress in the discussion...on the relevant legal regime on, and implementation gaps in conservation and sustainable use of marine genetic resources in areas beyond national jurisdiction in accordance with international law, in particular the United Nations Convention on the Law of the Sea, taking into account the views of States on Parts VII and XI of the Convention" ${ }^{84}$ Several States expressed their belief that the Working Group was the only international forum to discuss issues relating to marine biodiversity beyond national jurisdiction. ${ }^{85}$

${ }^{79}$ United Nations General Assembly, Report of the Secretary General, 64th Session Agenda Item 76, A/64/66/Add.2, (19 October 2009), p.64.

80 United Nations, General Assembly, Resolution Adopted by the General Assembly on 17 November 2004, Oceans and the Law of the Sea, A/RES/59/24, (4 February 2005), Para. 73.

81 United Nations, General Assembly, Report of the Ad Hoc Open-Ended Informal Working Group to study issues relating to the conservation and sustainable use of marine biological diversity beyond areas of national jurisdictions, A/61/65, (20 March 2006).

${ }^{82}$ United Nations, General Assembly, Oceans and the Law of the Sea, Resolution 59/24, A/RES/59/24, (4 February 2005).

${ }^{83}$ United Nations, Division for Ocean Affairs and the Law of the Sea, Marine Biological Diversity Beyond Areas of National Jurisdiction, Legal Policy and Framework, accessible at http://www.un.org/depts/los/ biodiversityworkinggroup/webpage_legal\%20and\%20policy.pdf.

${ }^{84}$ United Nations, General Assembly, Letter Dated 16 March 2010 from the Co-Chairpersons of the Ad Hoc Open-ended Informal Working Group to the President of the General Assembly: Recommendations of the Ad Hoc Open-ended Informal Working Group to study issues relating to the conservation and sustainable use of marine biological diversity beyond areas of national jurisdiction, A/65/68, Para. 19, (17 March 2010).

${ }^{85}$ Ibid., Para. 30. 


\section{B. The 2011 Package Deal}

In 2011, the Working Group submitted a recommendation to the General Assembly to initiate a process ensuring to address issues on sustainable use of marine biodiversity beyond national jurisdiction in a legal framework that has already existed or in developing a multilateral agreement under UNCLOS. In its recommendation, the Working Group stated that the process should include:

1. discussion on marine genetic resources, including issues of sharing of benefits;

2. area based management tool, including marine protected areas and environmental impact assessment;

3. capacity building as well as transfer of marine technology. ${ }^{86}$

The three elements are also referred to as the 2011 Package Deal. This proposal was adopted by the General Assembly through the Resolution of the General Assembly on 24 December 2011.87

The opposing views of the States,with respect to the resources in areas beyond national jurisdiction, remain apparent in the Working Group. Several delegations argued that exploitation of genetic resources in the Area had serious economic and social impacts. Biological resources of the Area was considered to be a part of the Common Heritage of Mankind which was contested by other delegates claiming that it only regulates matter concerning the mineral resources of the Area. ${ }^{88}$ Other proposal surfaced with the consideration that the concept of Common Heritage of Mankind was not only about profit sharing, but also about conservation and preservation. Therefore all aspects relating to the preservation and conservation of marine biodiversity should be addressed. ${ }^{89}$ Until January 2015 there were nine meeting held by the Working Group. The Working Group then reported to the United Nations General Assembly regarding the outcome of the discussions as well as its recommendations. The Working Group recommended the development of an international legally binding instrument under the UNCLOS and that the negotiations shall address the topics identified in the 2011 Package Deal. ${ }^{90}$

\section{The Preparation Committee}

Based on the report of the Working Group, in 2015 the General Assembly adopted the Resolution 69/292 which decided to develop an instrument of international legal character on the conservation and sustainable use of marine biological diversity

${ }^{86}$ United Nations, General Assembly, Letter Dated 30 June 2011 from the Co-Charis of the Ad Hoc Openended Informal Working Group to the President of the General Assembly: Recommendations of the Ad Hoc Open-ended Informal Working Group to study issues relating to the conservation and sustainable use of marine biological diversity beyond areas of national jurisdiction and Co-Chairs' summary of discussions, A/66/119, Para. 1 (b), (30 June 2011).

${ }^{87}$ United Nations, General Assembly, Resolution Adopted by the General Assembly on 24 December 2011, Oceans and the Law of the Sea, A/RES/66/231, Para. 167, (24 December 2011).

${ }^{88}$ United Nations, General Assembly, Letter Dated 30 June 2011, Para. 15 - 16.

${ }^{89}$ Ibid., Para. 17.

${ }^{90}$ United Nations, General Assembly, Letter dated 13 February 2015 from the Co-Chairs of the Ad-Hoc Open-ended Informal Working Group to the President of the General Assembly, A/69/780, Annex Para. 1 (e) (f), (13 February 2015). 
beyond national jurisdiction under UNCLOS. ${ }^{91}$ The General Assembly further established a preparatory committee in order to make recommendations to the Assembly on the elements of a draft of an international treaty. ${ }^{92}$ The Preparatory Committee was scheduled to convene from 28 March to 8 April 2016 and from 29 August to 12 September $2016 .{ }^{93}$ The Committee was tasked to report to the General Assembly on its progress by the end of $2017.9^{4}$

The substance that will be discussed in the Preparatory Committee are conservation and sustainable use of marine biological diversity in areas beyond national jurisdiction, marine genetic resources, sharing of benefits, area-based management tools, marine protected areas, environmental aspect assessment and transfer of marine technology, as well as capacity building. ${ }^{95}$ Several States have already expressed their opinions that a third implementing agreement to the Convention would respond to the urgent need to depart from the status quo, which was no longer acceptable. Furthermore, an international agreement would reduce existing governance gaps through a comprehensive legal and institutional framework. ${ }^{96}$

\section{INDONESIA AND BBNJ}

\section{A. A Continuum of International Engagement}

The Indonesian Constitution of 1945 mandated Indonesia to be actively involved in the preservation of world's peace. This was interpreted as a duty of Indonesia to play an active role in international sphere, including in the formation of international law. Indonesia realized the importance of international cooperation in reaching the goal of enhancing prosperity and maintaining peace and international order.

Historically, Indonesia has been actively involved in the law of the sea conferences which led to the creation of UNCLOS. During the Third Conference, Indonesia was also a supporter of the regime of the common heritage of mankind in the deep seabed area. ${ }^{97}$ Indonesia has been actively involved in the International Seabed Authority, an institution established by UNCLOS with the function to organize and control activities in the Area. ${ }^{98}$ Ambassador Hasjim Djalal of Indonesia was appointed as the first President of the International Seabed Authority Assembly. Since 1996, Indonesia has always been a member of the Council. These involvements indicated Indonesia's

\footnotetext{
${ }^{91}$ United Nations, General Assembly, Development of an international legally binding instrument under the United Nations Convention on the Law of the Sea on the conservation and sustainable use of marine biological diversity of areas beyond national jurisdiction, A/RES/69/292, Para. 1, (19 June 2015).

${ }_{92}$ Ibid., Para. 1(b).

${ }_{93}$ Ibid., Para. 1(c).

${ }^{94}$ Ibid., Para. 1(a).

95 Ibid., Para. 2.

${ }^{96}$ United Nations, General Assembly, Letter Dated 13 February 2015 from the Co-Chairs of the Ad Hoc Open-ended Informal Working Group to the President of the General Assembly: Outcome of the Ad Hoc Openended Informal Working Group to study issues relating to the conservation and sustainable use of marine biological diversity beyond areas of national jurisdiction and Co-Chair's summary of discussions, A/69/780, Para. 12, (13 February 2015).

${ }^{97}$ Steven Kotz, "The Common Heritage of Mankind: Resource Management of the International Seabed," Ecology Law Quarterly 6, No. 1 (1976): 78. The Paper provides comprehensive information concerning the interest of states with respect to the Common Heritage of Mankind issue.

${ }^{98}$ UNCLOS, art. 157 para. 1.
} 
commitment in ensuring the fair and equitability practice of the Authority. ${ }^{99}$

Indonesia remains further committed to ensuring that the law of the sea is upheld. In 2015, Indonesia was re-elected as a Category C Member of the International Maritime Organization (IMO) Council at its $29^{\text {th }}$ Assembly meeting. ${ }^{100}$ Indonesia is also a member in various Regional Fisheries Management Organization, such as the Indian Ocean Tuna Commission, Commission on Conservation of Southern Bluefin Tuna, and the Western and Central Pacific Fisheries Commission.

Indonesia has made a partial submission in respect of the area of northwest of Sumatra in 2008. ${ }^{101}$ The submission was adopted at the $27^{\text {th }}$ session of the Commission on the Limits of the Continental Shelf on 28 March 2011. ${ }^{102}$ Furthermore, as an archipelagic state, Indonesia submitted in 1996 to the IMO their designated archipelagic sea lane passage consisting of three north-south corridors. ${ }^{103}$ Indonesia has further deposited its list of the geographical coordinates of archipelagic baselines. ${ }^{104}$ The experiences Indonesia had with international organizations relating to the law of the sea strongly suggest Indonesia's eagerness to establish and uphold the rule of law in the oceans. Indonesia's contribution has been recognized, among others, through the election of Ambassador Arief Havas Oegroseno as the President of the Meeting of State Parties to UNCLOS 2010-2011. ${ }^{105}$

Therefore with respect to the BBNJ issue, Indonesia ought to put its attention to. Indonesia should remain committed in contributing positively to the better governance of the oceans which will address the challenges of the $21^{\text {st }}$ Century, while at the same time securing its national interest. As a party to the UNCLOS, as well as part of the international community, it is in Indonesia's interest to have a clear regulation concerning the BBNJ. Additionally, Indonesia has a particular concern due to its geographic condition, a similar situation was encountered when Indonesia advocated the archipelagic state regime.

${ }^{99}$ International Seabed Authority, Statement by the Delegation of the Republic of Indonesia at the Special Session Commemorating the 20th Anniversary of the International Seabed Authority, (Kingston, 22 July 2014), available at http://www.isa.org.jm/files/documents/EN/20Sess/SpecialSess/Indonesia.pdf.

100 Ministry of Transportation of the Republic of Indonesia, "Indonesia Terpilih Kembali sebagai Anggota Dewan IMO 2016-2017 [Indonesia is Re-elected as Member of the IMO Council 2016-2017]", available at http://www.dephub.go.id/berita/baca/indonesia-terpilih-kembali-sebagai-anggota-dewanimo-2016-2017/?cat=U2lhcmFuIFBlcnN8c2VjdGlvbi02NQ==, accessed on 2 March 2016.

101 See Indonesia, "Partial Submission in respect of the area of North West of Sumatra, Executive Summary," http://www.un.org/depts/los/clcs_new/submissions_files/idn08/Executive20Summary.pdf, accessed on 25 March 2016.

${ }^{102}$ Commission on the Limits of the Continental Shelf, "Agenda Item 4: Submission made by Indonesia in respect of North West of Sumatra Island" in Statement by the Chairperson of the Commission on the Limits of the Continental Shelf on the progress of work in the Commission, CLCS/70, (11 May 2011).

${ }^{103}$ Chris Forward, "Archipelagic Sea Lanes in Indonesia, Their Legality in International Law", available at http://www.austlii.edu.au/au/journals/ANZMarLawJl/2009/15.pdf, accessed on 2 March 2016.

104 United Nations, Deposit by the Republic of Indonesia of a list of geographical coordinates of points, pursuant to Article 47, paragraph 9, of the Convention, 09/105, (25 March 2009).

105 Ministry of Foreign Affairs of the Republic of Indonesia, "The 20th Meeting of State Parties to UNCLOS”, available at http://pustakahpi.kemlu.go.id/content.php?content=file_kegiatandetail\&id=5\&jeni s=Konferensi, accessed on 2 March 2016. 


\section{B. Indonesia's Geographical Location Facing the Areas Beyond National Jurisdiction}

Indonesia is an archipelagic state surrounded by vast areas beyond national jurisdiction, namely the Indian Ocean in the West, the Pacific Ocean in Northeast, and also borders the South China Sea in the North. The oceans surrounding Indonesia are known for its rich natural resources. In the Indian Ocean alone, various research have discovered the existence of numerous deep-sea habitats, meiofauna, macrofauna, megafauna, and seamounts. ${ }^{106}$ Various expeditions uncovering the biodiversity in the Pacific Ocean as well as in the South China Sea also show the richness of the oceans, notwithstanding those which have not been discovered yet. ${ }^{107}$

These oceans are part of a unified marine ecosystem which does not follow the maritime zone as determined by international law. Hence, it raises issues concerning highly migratory species, anadromous stocks, catadromous stock, which are properly addressed by UNCLOS. Similarly, the issue of BBNJ for Indonesia will raise the same concern. The ocean community that are found in the edge of Indonesia's jurisdiction will most likely continue to exist in the area beyond national jurisdiction. The management regime for this type of biodiversity will require a special arrangement as there is a possibility that certain organisms will live partially within and beyond Indonesia's jurisdiction.

The negotiation concerning highly migratory species and alike in the law of the sea conference was discussed in the context of fisheries, which also commonly referred to as the issue of straddling fish stock. In this regard, UNCLOS required states to cooperate, either directly or indirectly, in measures for conservation and development of the fishing resources. ${ }^{108}$ However, as discussed earlier in this paper, drawing such analogy from fisheries to the issue of BNNJ is subject to debate between countries, in particular with regard to the utilization of marine genetic resources.

\section{Overlapping Jurisdiction on Indonesia's Extended Continental Shelf and the Superjacent Waters}

Indonesia has made claims of a Continental Shelf beyond 200 nautical miles. Pursuant to UNCLOS, a country that claims more than 200 nautical miles of Continental Shelf must submit the claim to the Commission on the Limits of the Continental Shelf. The Commission will then proceed with a recommendation to establish the outer limit of the Shelf. The outer limits delineation based on the recommendation is then regarded final and binding. ${ }^{109}$

In this regard, Indonesia already received a recommendation from the Commission on the Limits of the Continental Shelf (CLCS) with regard to the Continental Shelf

106 Mohideen Wafar, et. al., "State of Knowledge of Coastal and Marine Biodiversity of Indian Ocean Countries”, PLoS ONE 6, no. 1 (31 January 2011), doi:http://dx.doi.org/10.1371/journal.pone.0014613.

${ }_{107}$ For further reading concerning the biodiversity in the Pacific Ocean, See Miloslavich et.al, "Marine Biodiversity in the Atlantic and Pacific Coasts of South America: Knowledge and Gaps," available at http:// www.ncbi.nlm.nih.gov/pmc/articles/PMC3031619/.

For further reading concerning the biodiversity in the South China Sea, See Liu JY, "Status of Marine Biodiversity of the China Seas", PLOS One 8, no. 1, doi: http://dx.doi.org/10.1371/journal.pone.0050719

${ }^{108}$ UNCLOS, art. 63.

109 Ibid., art. 76 para. 8. 
beyond 200 nautical miles in the northwest of Sumatra Island. ${ }^{110}$ Meanwhile, Indonesia has also indicated that it will make submission with regard to its outer limit of Continental Shelf beyond 200 nautical miles in the areas South of Nusa Tenggara and North of Papua.

Under this circumstance, there will be an overlap between Indonesia's designated Continental Shelf beyond 200 nautical miles and the superjacent waters which fall under the High Seas regime. In such scenario, UNCLOS has determined that the rights of the coastal state over the Continental Shelf do not affect the legal status of the superjacent waters, which in the case of Continental Shelf beyond 200 nautical miles is the High Seas. ${ }^{111}$ There will likely be a debate arising on who has the rights to exploit the biodiversity that exist in the High Seas but above Indonesia's Continental Shelf beyond 200 nautical miles.

A distinction between the regime of Continental Shelf and its superjacent waters has also been addressed by UNCLOS with regards to sedentary species. UNCLOS defined sedentary species as organisms which at the harvestable stage are either immobile on or under the sea-bed or are unable to move except in constant physical contact with the seabed or the subsoil. ${ }^{112}$ A Coastal State has sovereign rights over this sedentary species which falls under the regime of Continental Shelf pursuant to the provisions of Part VI UNCLOS. ${ }^{113}$ It has been explicitly excluded from the regime of Exclusive Economic Zone. ${ }^{114}$ This implies that sedentary species do not belong to any regime that governs the water column of the oceans. One might question, however, whether such provisions could be attributed to biological organisms that live in deep seabed. Additionally, genetic resources could be found at any stage of an organism lifespan. In this regard, in the situation where Indonesia has a Continental Shelf beyond 200 nautical miles, it will be difficult to draw the line whether marine genetic resources belong to the resources of the seabed or the High Seas.

\section{Transfer of Technology and Access to Genetic Resources}

As a Party to UNCLOS, CBD, and the Nagoya Protocol, Indonesia would expect the provisions concerning the transfer of technology and access to genetic resources. In spite of the positive growth in the past decade, Indonesia is still considered as a developing country. Indonesia is a member of the G77, along with other developing states. At this very moment Indonesia is yet to develop its capacity to take benefit directly from the resources of the areas beyond national jurisdiction. Indonesia currently does not possess the technology to undergo a marine scientific research that penetrates to the bottom of the ocean or acquiring biodiversity that exist there. Hence, Indonesia needs the transfer of technology and access to genetic resources.

On another note, Indonesia is eager to elevate itself in terms of economy, technology, and industry. Since 2008, Indonesia has become a member of the G-20, a group of 20 major economies in the world. As Indonesia continues to project its growth, it will soon be able to reach its potential of benefitting from various natural resources, particularly newly discovered resources in the oceans. Therefore it is expected that Indonesia would secure access to marine genetic resources as it develop its capacity so in the future in can also obtain the benefit from its resources.

\footnotetext{
${ }^{110}$ Forward, "Archipelagic Sea Lanes"

${ }^{111}$ UNCLOS, art. 78 para. 1.

112 Ibid., art. 77 para. 4.

${ }^{113}$ Ibid., art. 77 para. 1.

${ }^{114}$ Ibid., art. 68.
} 


\section{CONCLUSION AND RECOMMENDATION}

The current legal regime within UNCLOS creates a lacunae with regards to Biodiversity in Areas Beyond National Jurisdiction (BBNJ). The debate between developing and developed states evolves around the proper regime that governs $\mathrm{BBNJ}$ with regards to its utilization, as well as its conservation. Developing countries argued that BBNJ shall be part of common heritage of mankind, hence falling under the regime of Part XI. On the other hand, developed states are of the opinion that BBNJ falls under the regime of Part VII which treats them as part of the freedom of the High Seas. None of the arguments provide acceptable solution.

Other existing international law instruments namely the Convention on Biological Diversity (CBD) with its Nagoya Protocol do touch upon the issue of genetic resources, however they are concerned mainly with the resources within national jurisdiction. It also touches the issue of protection of intellectual property rights on whether a biological resources in its natural form could be granted patent rights.

An interesting observation of the ongoing debate between the regime of Part VII and Part XI reminded us on the traditional debate of Mare Clausum v. Mare Liberum in the $16^{\text {th }}$ Century. Back then, the discourse was whether States could claim the oceans as part of a nation's sovereignty. While now, the international community is debating the issue of BBNJ. The abovementioned traditional debate was practically settled with UNCLOS as a compromise for all States' interest. It is yet to be seen if another compromise with regard to the BBNJ can be achieved through a new international regulation.

The road to the new international regulation has been started. The United Nations has established a Working Group in 2006 to discuss the matter. In 2015 it was decided by the General Assembly to develop a legal instrument to address the conservation and protection of biological diversity beyond national jurisdiction. The Preparatory Committee will convene in March 2016 in the attempt to formulate a recommendation to the General Assembly to draft an international legal instrument. This is a very important step taken by the United Nations as a new international treaty will provide a legal certainty on the regime of the BBNJ. Thus upholding the rule of law in the world oceans.

Indonesia, as the largest Archipelagic State in the world, and a strong supporter of UNCLOS and the rule of law, should be actively engaged in the drafting process of this new treaty. In the BBNJ issue, Indonesia has a particular interest due to its geographical position as well as its future economy and technology projection. More importantly, Indonesia's engagement will serve as a fulfillment of its constitutional obligation to actively participate in the maintenance of world's peace and preserving international order. The development of BBNJ is very important for Indonesia as it will allow Indonesia to have a fair share with other nations in the world of the rich resources contained in the ocean.

Considering the multi-dimensional nature of the BBNJ issue, a comprehensive approach should be taken accordingly. Although it will be commenced under UNCLOS, it should also take into account other international instruments such as the CBD in order to enable a comprehensive mechanism settings. Similarly, in formulating national stance, all states including Indonesia should involve all stakeholders, ranging from the general public, law of the sea experts, intellectual property rights experts, and 
others. The involvement of all stakeholders will allow states to have a comprehensive view of its national interest.

It is very essential that the biodiversity beyond national jurisdiction could be enjoyed and benefit not only a handful of nations, but the entire global community. The positive progress of the discussion concerning BBNJ should be commended as it has moved from the debate on the existing legal regime to a consideration of establishing a new international treaty. Since the era of Grotius, States have always sought to regulate state's behavior in the oceans. This development on the issue of BBNJ attested the thesis that even four centuries after Grotius, mankind had never ceased in their quest to seeking the governance of the oceans in order to create stability and establish prosperity for all mankind. 


\section{Bibliography}

\section{Legal Documents}

Indonesia. Peraturan Pemerintah Pengganti Undang-Undang tentang Perairan Indonesia (Government Regulation in lieu of Law on Indonesian Waters), Perpu No. 4 Tahun 1960, LN No. 22 tahun 1960, TLN No. 1942 (Government Regulation in lieu of Law No. 4 of 1960, SG No. 22 of 1960).

Agreement establishing the World Trade Organization Annex 1C on Trade-Related Aspects of Intellectual Property Rights. Marrakesh, 15 April 1994. United Nations Treaty Series, Vol. 1867, No. 31874.

Convention on Biological Diversity. Rio de Janeiro, 5 June 1992.

, Conference of the Parties 2, Conservation and Sustainable Use of Marine and Coastal Biological Diversity, Decision II/10, (30 November 1995).

Conference of the Parties 10, Access to Genetic Resources and the Fair and Equitable Sharing of Benefits Arising from their Utilization, Decision X/1, (October 2010).

International Seabed Authority. Statement by the Delegation of the Republic of Indonesia at the Special Session Commemorating the $20^{\text {th }}$ Anniversary of the International Seabed Authority, (22 July 2013).

Nagoya Protocol. Nagoya, 29 October 2010.

Convention on the Law of the Sea. Montego Bay, 10 December 1982. United Nations Treaty Series Vo. 1833.

United Nations. General Assembly. Declaration of Principles Governing the Sea-Bed and the Ocean Floor, and the Subsoil Thereof, beyond the Limits of National Jurisdiction: Resolution 2479 (XXV), A/RES/25/2749, (17 December 1970).

- - - General Assembly. Report of the Secretary General 64 ${ }^{\text {th }}$ Session Agenda Item 76, A/64/66/Add.2, (19 October 2009).

- - - General Assembly. Resolution Adopted by the General Assembly on 17 November 2004, Oceans and the Law of the Sea, A/RES/59/24, (4 February 2005).

-_- General Assembly. Report of the Ad Hoc Open-Ended Informal Working Group to Study Issues Relating to the Conservation and Sustainable Use of Marine Biological Diversity Beyond Areas of National Jurisdictions, A/61/65, (20 March 2006).

- - - General Assembly. Letter Dated 16 March 2010 from the Co-Chairpersons of the Ad Hoc Open-ended Informal Working Group to the President of the General Assembly: Recommendations of the Ad Hoc Open-ended Informal Working Group to study issues relating to the conservation and sustainable use of marine biological diversity beyond areas of national jurisdiction, A/65/68, (17 March 2010).

-_- General Assembly. Letter Dated 30 June 2011 from the Co-Charis of the Ad Hoc Open-ended Informal Working Group to the President of the General Assembly: Recommendations of the Ad Hoc Open-ended Informal Working Group to study issues relating to the conservation and sustainable use of marine biological diversity beyond areas of national jurisdiction and Co- 
Chairs' summary of discussions, A/66/119, (30 June 2011).

- - - General Assembly. Resolution Adopted by the General Assembly on 24 December 2011, Oceans and the Law of the Sea, A/RES/66/231, (24 December 2011).

- - - General Assembly. Development of an international legally binding instrument under the United Nations Convention on the Law of the Sea on the conservation and sustainable use of marine biological diversity of areas beyond national jurisdiction, A/RES/69/292, (19 June 2015).

-_- General Assembly. Letter Dated 13 February 2015 from the Co-Chairs of the Ad Hoc Open-ended Informal Working Group to the President of the General Assembly: Outcome of the Ad Hoc Open-ended Informal Working Group to study issues relating to the conservation and sustainable use of marine biological diversity beyond areas of national jurisdiction and Co-Chair's summary of discussions, A/69/780, (13 February 2015).

- - - UNEP. Study of the Relationship between the CBD and UNCLOS with regard to the Conservation and Sustainable Use of Genetic Resources on the Deep Seabed, UNEP/CBD/SBSTATA/8/INF/3/Rev.1, (22 February 2003).

Vienna Convention on the Law of Treaties. Vienna, 23 May 1969.

World Intellectual Property Organization. Consolidated Document Relating to Intellectual Property and Genetic Resources for the $29^{\text {th }}$ Session 15-19 February 2016, WIPO/GRTKF/IC/29/4, (30 November 2015).

- - - General Assembly. Report of the Twenty-Sixth (12 ${ }^{\text {th }}$ Extraordinary) Session in Geneva, 25 September - 3 October 2000, WO/GA/26/10, (3 October 2000).

\section{Books}

Harrison, James. the Law of the Sea, A Study in the Development of International Law. Cambridge: Cambridge University Press, 2011.

Harrisse, Henry. The Diplomatic History of America. London: B. F. Stevens Publisher, 1897.

McDorman, Ted L., et al. International Ocean Law, Materials and Commentaries. Durham: Carolina Academic Press, 2005.

Millicay, Fernanda. "A Legal Regime for the Biodiversity of the Area", in Law, Science, and Ocean Management, edited by Myron H. Nordquist et al., 739-833, Leiden: Martinus Nijhoff, 2007.

Tuerk, Helmut. Reflections on the Contemporary Law of the Sea, Leiden: Martinus Nijhoff, 2012.

\section{Articles}

Blakeney, Michael. "Access to Genetic Resources: Some Concerns." International Intellectual Property Law and Policy 4 (2000): 61-1 - 61-12. 
Bonfanti, Angelica and Seline Trevisanut. "TRIPS on the High Seas: Intellectual Property Rights on Marine Genetic Resources." Brooklyn Journal of International Law 37 (2011-2012): 187-232.

de La Fayette, L.A. "A New Regime for the Conservation and Sustainable Use of Marine Biodiversity and Genetic Resources Beyond the Limits of National Jurisdiction." The International Journal of Marine and Coastal Law 24 (2009): 221-280.

Fletcher, Eric "John Selden and His Contribution to International Law," Transaction Grotius Society 19 No. 1 (1933): 1-12.

Kotz, Steven. "The Common Heritage of Mankind: Resource Management of the International Seabed." Ecology Law Quarterly 6, No. 1 (1976): 65-108.

Larschan, Bradley and Bonnie C. Brennan. "The Common Heritage of Mankind Principle in International Law." Columbia Journal of Transnational Law 21 (1982-1983): 305-337.

Lehmann, Friederike. "The Legal Status of Genetic Resources of the Deep Seabed." New Zealand Journal of International Law 11, No. 33 (2007): 33-65.

Liu, J.Y. "Status of Marine Biodiversity of the China Seas." PLOS ONE 8, no. 1 (2013). doi: http://dx.doi.org/10.1371/journal.pone.0050719.

Miloslavich, Patricia, et al. "Marine Biodiversity in the Atlantic and Pacific Coasts of South America: Knowledge and Gaps." PLOS ONE 6, no. 1 (2011). Accessed 2 March 2016. Doi: http://dx.doi.org/10.1371/journal. pone.0014631

van Ittersum, Martine Julia. "Mare Liberum versus the propriety of the seas? The debate between Hugo Grotius (1583-1645) and William Welwood (1552-1624) and its impact on Anglo-Scotto-Dutch fishery disputes in the second decade of the seventeenth century." Edinburgh Law Review 10, no. 2 (2006): 239-276.

Wafar, Mohideen, et al. "State of Knowledge of Coastal and Marine Biodiversity of Indian Ocean Countries." in PLoS ONE 6, no. 1 (2011). doi: http://dx.doi. org/10.1371/journal.pone.0014613.

Wisnumurti, Nugroho. "Rezim Hukum Negara Kepulauan [Legal Regime of an Archipelagic State]." Kompas. (18 March 2014).

\section{Websites}

Asian Development Bank. "Indonesia: Economy", http://www.adb.org/countries/ indonesia/economy. Accessed 2 March 2016.

Convention on Biological Diversity. "A History of the Convention", https://www.cbd. int/history/. Accessed 22 February 2016.

———. "List of Parties", https://www.cbd.int/information/parties.shtml. Accessed 1 March 2016.

———. "About the Nagoya Protocol", https://www.cbd.int/abs/about/default.shtml/. Accessed 1 March 2016

_—_. "Parties to the Nagoya Protocol", https://www.cbd.int/abs/nagoya-protocol/ 
signatories/default.shtml. Accessed 1 March 2016.

Forward, Chris. "Archipelagic Sea Lanes in Indonesia, Their Legality in International Law". http://www.austlii.edu.au/au/journals/ANZMarLawJl/2009/15. pdf. Accessed 2 March 2016.

Indonesia, Ministry of Transportation, "Indonesia Terpilih Kembali sebagai Anggota Dewan IMO 2016-2017" (Indonesia is Re-elected as Member of the IMO Council 2016-2017), http://www.dephub.go.id/berita/baca/indonesiaterpilih-kembali-sebagai-anggota-dewan-imo-2016-2017/?cat=U2lhc mFuIFBlcnN8c2VjdGlvbi02NQ==. Accessed 2 March 2016.

- - Ministry of Foreign Affairs, "The $20^{\text {th }}$ Meeting of State Parties to UNCLOS". http://pustakahpi.kemlu.go.id/content.php?content=file_kegiatandetai l\&id=5\&jenis=Konferensi. Accessed 2 March 2016.

United Nations, Division for Ocean Affairs and the Law of the Sea. "Marine Biological Diversity Beyond Areas of National Jurisdiction, Legal Policy and Framework", http://www.un.org/depts/los/ biodiversityworkinggroup/webpage_legal\%20and\%20policy.pdf.

Division of Ocean Affairs and the Law of the Sea. "Executive Summary of the Government of the Republic of Indonesia, Partial Submission in Respect of the Area of Northwest of Sumatra", http://www.un.org/depts/los/ clcs_new/submissions_files/idn08/Executive20Summary.pdf.

Zewers, Kirsten E. "Debated Heroes from the Deep Sea-Marine Genetic Resources". http://www.wipo.int/wipo_magazine/en/2008/02/article_0008.html. Accessed 23 February 2016. 